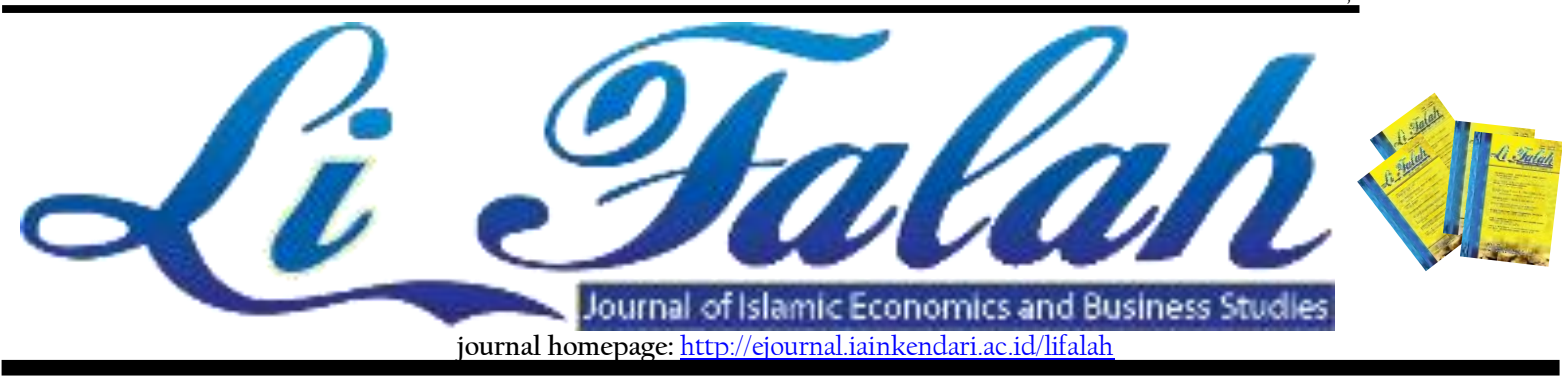

\title{
Moderating Knowledge on Planned Behaviour Theory Toward Intention of Using Islamic Financial Services
}

\author{
Anna Sardiana \\ Indonesia Banking School/Islamic Finance and Banking Dept, Indonesia \\ email: *anna.sardiana@ibs.ac.id
}

\begin{tabular}{|c|c|}
\hline ARTICLE INFO & A B S T R A C T \\
\hline Article History: & The study examines students' behavior described through planned \\
\hline Received 10 March 2021 & behavior (ТРВ) to use Islamic financial services by moderating \\
\hline $1^{\text {st }}$ Received in revised form & knowledge. Primary data was used with 350 samples of a random \\
\hline 29 January 2021 & population. Data were analyzed using Smart PLS assistance. The \\
\hline $2^{\text {st }}$ Received in revised form & results of this study indicate that there is a significant influence on \\
\hline $\begin{array}{l}28 \text { February } 2021 \\
3^{\text {st }} \text { Received in revised form }\end{array}$ & attitude has a positive relationship. Still, it does not substantially \\
\hline 15 march 2021 & affect the intention to use Islamic financial services. The subjective \\
\hline $4^{\text {st }}$ Received in revised form & norms and perceived behavioral control positively influence a \\
\hline 23 May 2021 & positive relationship with Islamic financial services. As for \\
\hline Available online 30 Juni 2021 & $\begin{array}{l}\text { moderating the choice to use Islamic financial services on the } \\
\text { personal norm variable, it has a negative direction but significant }\end{array}$ \\
\hline Keywords: & effect. On the other hand, the perceived behavioral control variable \\
\hline $\begin{array}{l}\text { IFS Utilization, Attitude, } \\
\text { Subiective Norm Perceived }\end{array}$ & has a positive relationship and significantly impacts using Islamic \\
\hline $\begin{array}{l}\text { Subjective Norm, Perceived } \\
\text { Behavioural Control, }\end{array}$ & financial services to moderate knowledge. Meanwhile, attitudes \\
\hline Knowledge. & moderating knowledge do not positively affect the intention to use \\
\hline$\frac{\text { http://dx.doi.org/10.31332/lif }}{\text { alah.v6i1.2507 }}$ & \\
\hline
\end{tabular}

\section{Introduction}

Some studies have found a relationship between financial literacy and the use of financial services. (Bongomin et al., (2017); Njoroge (2013); Simeyo et al., (2011); Lusardi and Tufano (2009)) Found that there is an influence between financial literacy and financial services. Specifically, Sardiana (2014) found an effect of Islamic financial literacy on the use of Islamic financial services.

In line with the findings in several of these studies, the third National Financial Literacy Survey (SNLIK) conducted by the Financial Services Authority (OJK) in 2019 showed that the financial literacy index increased to $38.03 \%$ inclusion reached 76.19 percent. This figure increases compared to the OJK survey results in 2016, namely the financial literacy index 
of 29.7 percent and the financial inclusion index of 67.8 percent. Thus, there was an increase in public financial understanding (literacy) by $8.33 \%$ in these three years and an increase in access to financial products and services (financial inclusion) by $8.39 \%$. This synergy and hard work show that the target of the financial inclusion index proclaimed by the government through Presidential Decree Number 82 of 2016 concerning the National Strategy for Financial Inclusion (SNKI) of 75\% in 2019 has been achieved (OJK, 2019).

As in 2016, SNLIK 2019 also uses the same methods, parameters, and indicators, namely the financial literacy index, which consists of parameters of knowledge and ability, while the financial inclusion index uses usage parameters. (OJK, 2019). Sardiana (2014), in her study, found that partially only indicators of knowledge have a significant influence on preferences for the use of Islamic financial services. In the tri component model, knowledge (cognitive) will give rise to feelings, and in the end, lead to action (Purwanto, (2016). The story shows an attitude towards something.

Correspondingly, attitude is prevalent in many studies (Spear and Singh, 2004). This finding is due to two reasons. First, that attitude can predict consumer behavior (Mitchell and Olson 1981). Second, several social psychology researchers have carried out several frameworks for research on philosophy (Eagly and Chaiken, 1993). Djou (2019) found that financial attitudes positively and significantly influence financial management behavior.

Planned Behaviour theory states that behavior is influenced by behavioral intention, which, in turn, is controlled by attitudes toward behavior. Attitudes can be defined as the results of consumer assessments of specific behaviors (Ajzen 1991). Thus, this study analyzes the effect of TPB on the intention to use Islamic financial services with the moderation of knowledge.

\section{Literature Review}

The theory most frequently cited about the attitude-behavior relationship is the planned behavior theory (TPB) (Ajzen 1991). The theory of planned behavior includes five essential dimensions that are considered capable of explaining human behavior: (i) attitudes towards certain behaviors, which measure the general attitudes of individuals and are identified as evaluative responses that reflect beliefs about those behaviors (Oskamp 1977); (ii) subjective norms, as social pressure that is felt to perform the behavior in which the individual is considered responsible for behaving following external opinions that influence what he does; and (iii) perceived behavioral control (PBC) refers to individual beliefs about their ability to perform certain behaviors based on their skills and external forces that can influence 
alternatives (Staats 2003). These three variables determine (iv) intention to perform behavior and (v) intention, which, in turn, directly influences behavior (Ajzen 1985).

TPB states that behavior is influenced by behavioral intention, which, in turn, is influenced by attitudes toward behavior. Attitudes can be defined as the results of consumer assessments of specific behaviors (Ajzen 1991). Many researchers study the attitude-behavior relationship when it comes to purchasing concerns, and all conclude that there is a wide gap between what consumers think and what they do about making purchase decisions (Eck 2009; Anon 2009; Finisterra et al. 2009; Basu and Hicks 2008; Darnall et al. 2012; Ferguson 2011). The popularity of attitude is reflected in the annual conferences on attitude sponsored by the American Marketing Association since the 1970s and often uses a hierarchy of effects models rooted in attitudes. Two attitude constructs appear particularly popular: attitudes toward brands, or A, purchase intentions (PI), or personal action tendencies related to brands (Bagozzi et al. 1979; Ostrom 1969). A and PI are routinely used in a variety of advertising domains, including copy testing, tracking studies, brand evaluation, and branding (Boush and Loken 1991; Broniarczykand Alba 1994; Hastak and Olson 1989; Kalwani and Si 1982; Keller and Aaker 1992; Morwitz, Johnson, and Schmittlein 1993).

The intention to behave is preceded by knowledge (Kotler, 2014). Saptasari's (2016) findings show that consumer knowledge has a positive and significant effect on consumer intention to use Islamic banks. This finding aligns with Pasi's (2017) findings, where knowledge can influence behavior. Knowledge is obtained from information received throughout his life. Attitudes provide an overview of the actions to be taken so that attitudes can influence a person's behavior in life. Knowledge about Islamic banking that the public accepts cannot be realized if you do not have a good attitude to be translated into action, namely becoming a customer of Islamic banks, which is a form of behavior. In other words, knowledge, attitudes, and actions are a unity of behavior. Likewise, the findings of Muflih et al. (2020) were used to examine the Behavioural Intention of Sharia Cooperative Savings Users by looking at the Role of Product Knowledge, Trust, Perceptions of Profits Perceptions of Quality. The results of these studies indicate that product knowledge and interest in saving have a positive and significant relationship.

Regarding research findings related to the relationship between TPB on the intention to use Islamic financial services and knowledge of using Islamic financial services, several studies were found to use Islamic financial services that used moderator variables. For example, in Akib and Santoso's research (2019), Subjective norms and perceived behavioral control were found to have a positive and significant effect on the intention to use Islamic bank products. In other research related to the use of Islamic financial services, both Amalia (2018) 
and Wahyuni, Basri, and Shabri (2019) found that there was an influence between TPB on the intention to use Islamic financial services where Amalia (2018) looked at the factors that influence the intention to use Sharia fintech with the TPB approach while Wahyuni, Basri and Shabri (2019) see the effect of TPB on the intention to have a Sharia-based home financing in the city of Banda Aceh. Mudrikah (2018) uses knowledge as a moderating variable in his research, which analyzes the effect of perceived returns on investment decisions in Islamic stocks with knowledge as a moderating variable. As for other research, Yoga (2020) and Hayati (2020) use religiosity as a moderating variable to use Islamic financial services. Besides, the moderating variable used in research related to the use of Islamic financial services includes religious commitment (Riza, 2018), service (Hamim, 2018), and financial literacy (Wijayantie, Nurachma, and Sunarsih, 2020).

\section{Research Method}

This study is a quantitative study using primary data obtained from the distribution of questionnaires to a student population with a total sample size of 350 respondents. The data was collected by using the purposive random sampling method. The research data were processed and analyzed using the SEM approach with Partial Least Square (PLS) as a method for model building and calculated with the help of SmartPLS V3.2.6 software. Using the PLS method shows the complexity of the relationship between one construct and another, as well as the relationship between a construct and its indicators. Two equations form PLS: the inner model, which determines the relationship between constructs and other constructs, and the outer model, which determines the relationship between constructs and their indicators.

\section{Result}


The of the respondent's data description based on gender, age, education, occupation, and monthly expenses can be seen as follows :

Respondent Characteristics Table

\begin{tabular}{llll} 
Profile of Respondents & \multicolumn{1}{c}{ Category } & Frequency & \multicolumn{1}{c}{ Percentage } \\
\hline Gender & Male & 141 & 40.3 \\
\cline { 2 - 4 } & Female & 209 & 59.7 \\
\hline Age & $18-28$ Years & 340 & 97.1 \\
\cline { 2 - 4 } & $29-38$ Years & 5 & 1.4 \\
\cline { 2 - 4 } & $39-48$ Years & 4 & 1.1 \\
\cline { 2 - 4 } & Over 49 Years & 1 & 0.3 \\
\hline Monthly Expenditures & l.000.001 - 3.000.000 & 202 & 57.7 \\
\cline { 2 - 4 } & $3.000 .001-5.000 .000$ & 31 & 8.9 \\
\cline { 2 - 4 } & $5.000 .001-10.000 .000$ & 12 & 3.4 \\
\cline { 2 - 4 } & Above 10.000.001 & 4 & 1.1 \\
\cline { 2 - 4 } & Below 1 Million & 101 & 28.9
\end{tabular}

Source: Primary Data Processed

The table of respondent characteristics shows that out of 350 respondents, most respondents based on gender are women, with a percentage of $59.7 \%$ or 209 respondents from a total of 350 respondents. In the age category, most respondents were 18-28 years old, with a percentage of $97.1 \%$ or 340 respondents out of 350 respondents in this age category and a total of 350 respondents. As for the monthly expenditure category, most respondents who use Islamic financial services in the monthly expenditure category are 1,000,000 - 3,000,001, where respondents in this monthly expenditure category reach 202 respondents $(57.7 \%$ of 350 respondents).

\subsection{Data Descriptions}

Statistical descriptions aim to describe or provide information about data or the state of a phenomenon. Statistical data deduction is only aimed at existing data sets. Based on the independent variables examined in this study, namely the intention to use Islamic financial services with knowledge moderation, it can be described that the mean of each indicator of the moderating research variable of knowledge on the intention to use Islamic financial services was answered by 350 respondents showing that the research sample was measured in a scale 1-5 where scale 5 is more significant than scale 1-4 which shows attitude, subjective norm, perceived behavioral control (PBC), knowledge level, and intention to use Islamic 
financial services. In general, the average value of a variable is between $3.35-4.13$. The lowest mean value is found in the subjective norm (SN2), which shows that the respondent's closest environment, namely family and friends, does not use Islamic financial services. The highest mean indicator value is in intention, where most respondents believe that regulators and their stakeholders guarantee Islamic financial services in Indonesia.

\subsection{Research Data Analysis}

This study's data analysis begins with testing the value of convergent validity, discriminant validity, and reliability testing of each variable in the study. The purpose of this validity test is to see whether or not the questions in the questionnaire are valid. Convergent validity is used to measure the value of the correlation between the indicator score and the construct score. A reliability test was conducted to determine the reliability level of the questionnaire. A reliable instrument is an instrument that will produce the same data when used several times to measure the same object. In SmartPLS, this correlation value is indicated by the outer loading value, the size of which individually is said to be high if the value is more than 0.7 with the construct being measured. Evaluation of the measurement model (outer model) can be done by looking at the results of indicator validity and construct reliability (convergent validity and discriminant validity)

\subsection{Construct Validity Testing}

The validity test is done using the evaluation measurement (outer) model, namely, using the convergent validity of each indicator's Loading Factor (LF). According to the rule of thumb (Haryono, 2017), indicators are valid if the LF value is $\geq 0.7$ against the intended variable. The following is the output measurement model or outer model with PLS: 


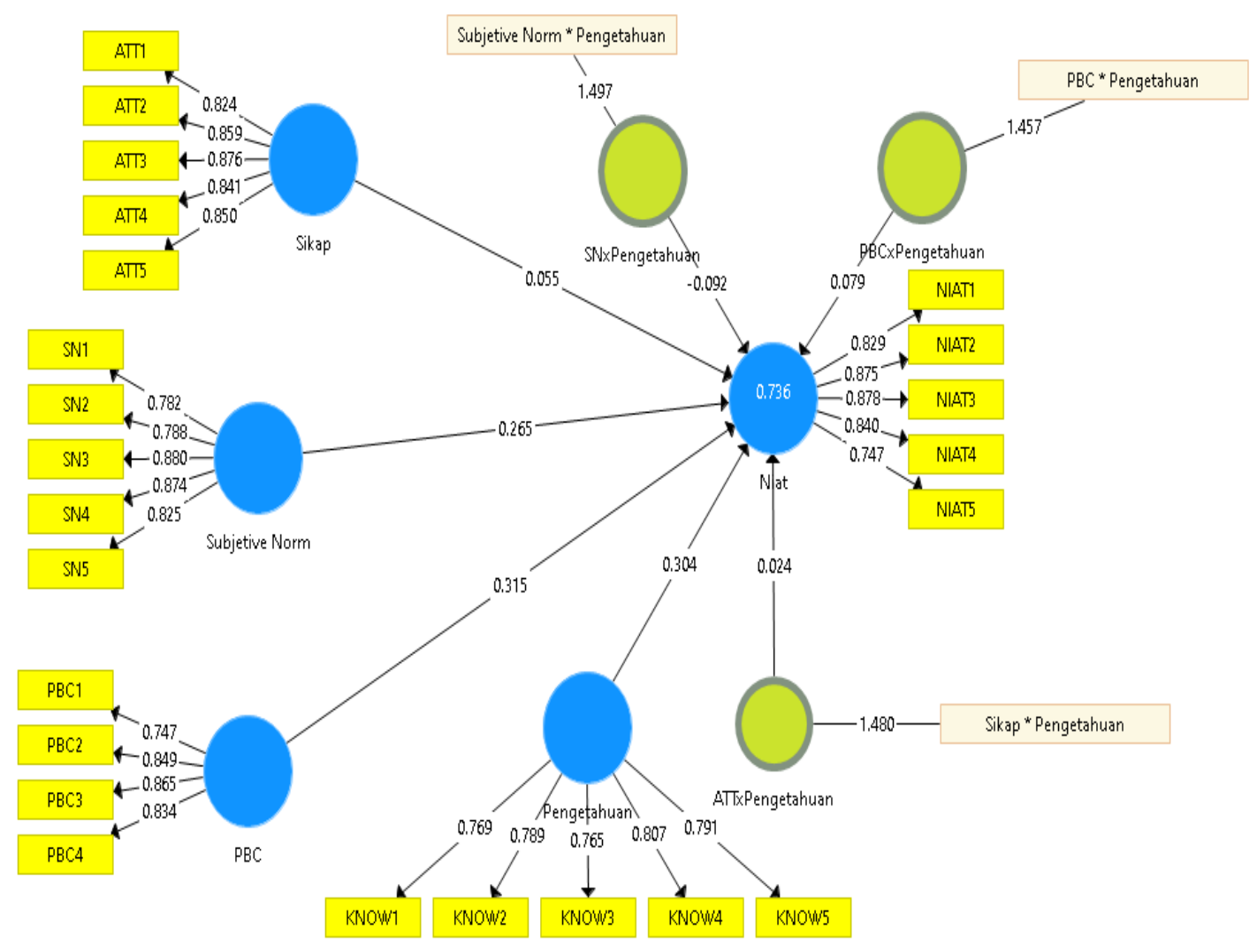

Outer Model Figures

Source: Processed SmartPLS, 2020

The output in the outer model image explains the relationship between latent variables and their indicators. Besides, the LF value also shows the convergent validity criteria, which can be analyzed as follows:

a. Attitude / Attitude has five indicators, namely ATT1, ATT2, ATT3, ATT4, and ATT5. These five indicators have a loading factor (LF) as follows: ATTl with a loading factor of 0.824 , ATT2 has an LF value of 0.859, ATT3 has an LF value of 0.876, ATT4 has an LF value of 0.84l, while the ATT5 indicator has a loading factor of 0.850 . Thus, these five indicators are included in the criteria for convergent validity because they have an LF value of $\geq 0.7$.

b. Subjective Norm has five indicators, namely SN1, SN2, SN3, SN4, and SN5. Of these five indicators, the loading factor is $\mathrm{SN1}$ with a loading factor of 0.782 , SN2 has an LF value of 0.788 , SN3 has an LF value of 0.880 , SN4 has an LF value of 0.874 , while the SN5 indicator has a loading factor of 0.825 . Thus, these five indicators are included in the criteria for convergent validity because they have an LF value of $\geq 0.7$.

c. Perceived Behavioural Control has five indicators, namely $\mathrm{PBCl}, \mathrm{PBC} 2, \mathrm{PBC} 3$, and PBC4. Of the four indicators, each has a loading factor: $\mathrm{PBCl}$ with a loading factor of 0.747 , PBC2 has an LF value of 0.849 , and PBC3 has an LF value of 0.865 PBC4 has an LF value of 
0.834. Thus, these five indicators are included in the criteria for convergent validity because they have an LF value of $\geq 0.7$.

d. Knowledge has five indicators, namely KNOW1, KNOW2, KNOW3, KNOW4, and KNOW5. Of these five indicators, the loading factor is as follows: KNOWl with a loading factor of 0.769 , KNOW2 has an LF value of 0.789 , KNOW3 has an LF value of 0.765 , KNOW4 has an LF value of 0.807, while the KNOW5 indicator has a loading factor of 0.791 . Thus, these five indicators are included in the criteria for convergent validity because they have an LF value of $\geq 0.7$.

e. Intention has five indicators, namely NIAT1, NIAT2, NIAT3, NIAT4, and NIAT5. Of these five indicators, the loading factor is as follows: NIATl has a loading factor of 0.829, NIAT2 has an LF of 0.875 , NIAT3 has an LF of 0.878 , NIAT4 has an LF of 0.840 , while the NIAT5 indicator has a loading factor of 0.747 . Thus, these five indicators are included in the criteria for convergent validity because they have an LF value of $\geq 0.7$.

The following table shows the Validity Test results with Discriminant Validity. All variables have met the criteria where the AVE value is $>0.5$ so that all indicators are considered valid to measure latent variables. While the Reliability Test with Composite Reliability and Cronbach's alpha shows that all latent variables have a composite reliability value of> 0.8 , meaning that all independent latent variables are appropriate and feasible to be used as the tested variables to determine their effect on the latent dependent variable, namely the intention to use Islamic financial services. Cronbach alpha shows $\geq 0.6$, which means that all variables in this study are consistent in testing the moderation of knowledge on the intention to use Islamic financial services.

AVE, Composite reliability and Cronbach's alpha Table

\begin{tabular}{llll}
$\begin{array}{l}\text { Variable } \\
\text { Extracted (AVE) }\end{array}$ & $\begin{array}{l}\text { Average } \\
\text { Eariance }\end{array}$ & Composite Reliability & Cronbach's Alpha \\
\hline Attitude (ATT) & 0.723 & 0.929 & 0.904 \\
\hline Subjective Norm & 0.690 & 0.917 & 0.887 \\
\hline PBC & 0.681 & 0.895 & 0.843 \\
\hline Knowledge & 0.615 & 0.889 & 0.844 \\
\hline Intention & 0.698 & 0.920 & 0.891 \\
\hline ATTx Knowledge & 1.000 & 1.000 & 1.000 \\
\hline SNx Knowledge & 1.000 & 1.000 & 1.000 \\
\hline PBCx Knowledge & 1.000 & 1.000 & 1.000 \\
Source: Processed SmartPLS, 2020 & & &
\end{tabular}


In the Structural Model Analysis (Designing the Inner Model), R Square's output value is 0.736 . This $\mathrm{R}$ Square result number explains that the influence of the variable Attitude (ATT), Subjective Norm (SN), Perceived Behavioural Control (PBC), Knowledge (KNOW), and Intention (NIAT) gives a value of 0.736 , which can be interpreted that the latent dependent variable can be explained by the independent latent variable of $73.6 \%$. In comparison, other variables explain the remaining $26.4 \%$ outside of this research model. From this figure, it can be categorized that the dependent variable can be defined by the independent variable on a moderate scale.

The Adjusted R Square has a value with an interval between 0 and 1 . If the Adjusted R Square value is getting closer to 1 , the independent latent variable $(\mathrm{X})$ explains the variation of the latent dependent variable (Y) better. The Adjusted R Square value was 0.730 or $73 \%$ in this study. So it can be concluded that the independent latent variable can explain $73 \%$ of the variations in variable $Y$. In contrast, the rest is explained by other variables not included in the model.

\subsection{Hypothesis test}

Hypothesis testing in this study uses direct effect analysis. Immediate effect analysis helps test the hypothesis of a variable's direct effect that affects (exogenous) the affected variable (endogenous). In testing this hypothesis, what is analyzed is the path coefficient and the p-value generated from the PLS Bootstrapping output with the Bootstrapping Path Coefficient output as follows:

Bootstrapping-PLS Output Summary Table

\begin{tabular}{lrrrrrr} 
& $\begin{array}{l}\text { Original } \\
\text { Sample } \\
(\mathrm{O})\end{array}$ & $\begin{array}{l}\text { Sample } \\
\text { Mean } \\
(\mathrm{M})\end{array}$ & $\begin{array}{l}\text { Standard } \\
\text { Deviation } \\
(\text { STDEV })\end{array}$ & $\begin{array}{l}\text { T Statistics } \\
(|\mathrm{O} / \mathrm{STDEV}|)\end{array}$ & P Values \\
\hline Attitude $\rightarrow$ Intention & 0,055 & 0,060 & 0,050 & 1,089 & 0,138 \\
\hline Subjetive Norm $\rightarrow$ Intention & 0,265 & 0,264 & 0,071 & 3,743 & 0,000 \\
\hline PBC $\rightarrow$ Intention & 0,315 & 0,308 & 0,051 & 6,196 & 0,000 \\
\hline $\begin{array}{l}\text { Knowledge } \rightarrow \text { Intention } \\
\text { ATTx Knowledge } \rightarrow\end{array}$ & 0,304 & 0,307 & 0,073 & 4,186 & 0,000 \\
$\begin{array}{l}\text { Intention } \\
\text { SNx Knowledge } \rightarrow \text { Intention }\end{array}$ & 0,024 & 0,025 & 0,053 & 0,455 & 0,325 \\
$\begin{array}{l}\text { PBCx Knowledge } \rightarrow \\
\text { Intention }\end{array}$ & $-0,092$ & $-0,093$ & 0,051 & 1,799 & 0,036 \\
\multicolumn{1}{l}{ Source: Processed SmartPLS, 2020 } & 0,079 & 0,078 & 0,042 & 1,894 & 0,029 \\
\end{tabular}


1. Hypothesis Testing The Effect of Attitude on Intention to Use Islamic Financial Services. The bootstrapping table (Path Coefficient) above shows the original sample value of 0.055 and a $\mathrm{p}$-value of 0.138 . With a significance level of $5 \%=0.05$, the measurement results show $0.138>0.05$ or a $\mathrm{p}$-value> 0.05 , it can be concluded that the first hypothesis in this study is rejected. Thus, based on the data from the bootstrapping results (Path Coefficient), it can be interpreted that the sample data for the independent latent variable (Attitude) has a positive relationship directly with the latent dependent variable (intention) but is not significant or in other words attitude does not have a significant influence on Intention to Use Islamic financial services with a positive relationship direction.

2. Hypothesis Testing The Influence of Subjective Norms on Intention to Use Islamic Financial Services. The bootstrapping table (Path Coefficient) above shows the original sample value of 0.265 and a $\mathrm{p}$-value of 0.000 . With a significance level of $5 \%=0.05$, the measurement results show $0.000<0.05$ or a $\mathrm{p}$-value $<0.05$, it can be concluded that the first hypothesis in this study is accepted. Thus, based on the data from the bootstrapping results (Path Coefficient), it can be interpreted that the sample data for the independent latent variable Subjective Norm has proven to be a positive and significant relationship with the latent dependent variable (intention), or in other words Subjective Norm (Subjective Norm). ) has a significant influence on the Intention of Using Islamic financial services positively.

3. Hypothesis Testing The Effect of Perceived Behavioural Control (PBC) on the Intention of Using Islamic Financial Services. The bootstrapping table (Path Coefficient) above shows the original sample value of 0.315 , a p-value of 0.000 . With a significance level of $5 \%=0.05$, the measurement results show $0.000<0.05$ or a $\mathrm{p}$-value $<0.05$, it can be concluded that the first hypothesis in this study is accepted. Thus, based on the data from the bootstrapping results (Path Coefficient), it can be interpreted that the sample data for the independent latent variable Perceived Behavioural Control (PBC) succeeds in proving a positive and significant relationship with the latent dependent variable (intention), or in other words Perceived Behavioural Control (PBC). ) has a significant influence on the Intention of Using Islamic financial services positively.

4. Hypothesis Testing The Influence of Knowledge (KNOW) on the Intention of Using Islamic Financial Services. The bootstrapping table (Path Coefficient) above shows the original sample value of 0.304 and a $p$-value of 0.000 . With a significance level of $5 \%=0.05$, the measurement results show $0.000<0.05$ or a $\mathrm{p}$-value $<0.05$, it can be concluded that the first hypothesis in this study is accepted. Thus, based on the data from the bootstrapping results (Path Coefficient), it can be interpreted that the sample data of the independent latent variable Knowledge (KNOW) has proved a positive and significant relationship with the latent 
dependent variable (intention), or in other words Knowledge (KNOW) has a significant influence. Towards the Intention of Using Sharia financial services with a positive direction.

5. Hypothesis Testing The Effect of Attitude on Intention to Use Islamic Financial Services with Knowledge as a Moderating Variable. The bootstrapping table (Path Coefficient) above shows the original sample value of 0.024 and a p-value of 0.325 . With a significance level of $5 \%=0.05$, the measurement results show $0.325>0.05$ or a $p$-value 0.05 , it can be concluded that the first hypothesis in this study is rejected. Thus, based on the data from the bootstrapping results (Path Coefficient), it can be interpreted that the knowledge variable sample data does not significantly moderate the effect of attitudes on the dependent variable (intention to use Islamic financial services), or in other words, ATT * KNOW does not have a significant effect on NIAT with positive relationship direction.

6. Hypothesis Testing on the Effect of Subjective Norms on Intention to Use Islamic Financial Services with Knowledge as a Moderating Variable. The bootstrapping table (Path Coefficient) above shows the original sample value of -0.092 and a $\mathrm{p}$-value of 0.036 . With a significance level of $5 \%=0.05$, the measurement results showed $0.036<0.05$ or a $p$-value $<0.05$, it can be concluded that the first hypothesis in this study was accepted. Thus, based on the data from the bootstrapping results (Path Coefficient), it can be interpreted that the sample data of the knowledge variable significantly moderate the effect of the Subjective Norm (Subjective Norm) on the dependent variable (intention to use Islamic financial services), or in other words, $\mathrm{SN} * \mathrm{KNOW}$ has a significant effect. Towards INTENTION with an antagonistic relationship direction.

7. Hypothesis Testing on the Effect of Perceived Behavioural Control (PBC) on Intention to Use Islamic Financial Services with Knowledge as a Moderating Variable. The bootstrapping table (Path Coefficient) above shows the original sample value of 0.079 and a $\mathrm{p}$-value of 0.029 . With a significance level of $5 \%=0.05$, the measurement results showed 0.029 $<0.05$ or a $\mathrm{p}$-value $<0.05$, it can be concluded that the first hypothesis in this study was accepted. Thus, based on the data from the bootstrapping results (Path Coefficient), it can be interpreted that the data sample of knowledge variables can moderate the effect of Perceived Behavioural Control (PBC) on the dependent variable (intention to use Islamic financial services), or in other words, PBC*KNOW has a significant effect. Towards INTENTION with a positive relationship direction.

Based on the results of the hypothesis test above, here are the overall results that show the conclusion of the hypothesis test:

Hypothesis Testing Conclusion Table 


\begin{tabular}{lcccr} 
& $\begin{array}{l}\text { Original } \\
\text { Sample } \\
\text { (O) }\end{array}$ & $\begin{array}{l}\text { Direction of } \\
\text { Relationships }\end{array}$ & P Values & Conclusion \\
\hline Attitude $\rightarrow$ Intention & 0,055 & Positive & 0,138 & Not significant \\
\hline Subjetive Norm $\rightarrow$ Intention & 0,265 & Positive & 0,000 & Significant \\
\hline PBC $\rightarrow$ Intention & 0,315 & Positive & 0,000 & Significant \\
\hline Knowledge $\rightarrow$ Intention & 0,304 & Positive & 0,000 & Significant \\
\hline ATTx Knowledge $\rightarrow$ Intention & 0,024 & Positive & 0,325 & Significant \\
\hline SNx Knowledge $\rightarrow$ Intention & $-0,092$ & Negative & 0,036 & Significant \\
\hline PBCx Knowledge $\rightarrow$ Intention & 0,079 & Positive & 0,029 &
\end{tabular}

Based on the conclusion table above, it can be seen that attitudes have a positive relationship but have no significant effect on the intention to use Islamic financial services. The subjective norms and perceived behavioral control significantly influence a positive relationship to use Islamic financial services. As for moderating knowledge of the intention to use Islamic financial services on the subjective norm variable, it has a negative direction but significant effect. In the variable, perceived behavioral control has a positive relationship and significantly affects the intention to use Islamic financial services with the moderation of knowledge. Meanwhile, attitudes moderating knowledge do not significantly affect the intention to use Islamic financial services but positively.

\section{Discussion}

Based on statistical calculations in this study, it can be concluded that the attitude construct variable does not significantly affect the intention to use Islamic financial services. However, the better the attitude will increase the intention to use Islamic financial services. According to the results of this study, it can be interpreted that a person's behavior or attitude does not affect the intention to use Islamic financial services. This data illustrates that students generally have behavior or attitude that is relatively indifferent to Islamic financial services. In Banowati and Sholeh's (2018) findings, this is influenced by several factors, including understanding the principles of Islamic savings, level of religiosity, socio-cultural factors, perceptions of Islamic banking simultaneously to save in Islamic Bank.

The theory that explains the relationship between attitude and behavior says that actual behavior will appear if the individual concerned intends to manifest the behavior. Meanwhile, the formation of an intention to behave is directly influenced by the person's 
attitude to behave and the subjective norms that the individual has (Elfrida, 2006). Therefore, the positive relationship on attitudes towards intention in this study shows that the better the attitude, the more likely it will be to use Islamic financial services.

The results of this study are also in line with Saud's (2016) results and Park and Blenkinsopp's (2009) that attitude has no significant effect on intention. However, the results contradict the findings of Banowati and Sholeh (2018), Elfrida (2006), Dunn et al. (2001); Downs (2006); Dominanto (2008); Ahmadi et al. (2010) found that attitudes have a positive and significant effect in explaining intentions.

Meanwhile, on the influence of subjective norms on the intention to use Islamic financial services, this study is consistent with the research of Mukodim (2007), Marhaini (2008), Bellman (2009), and Istiana (2010) concluded that subjective norms have a significant effect on intention.

Thus, even though it is not directly in line with the hypothesis about the influence of belief on the use of Islamic financial services, self-confidence as a dimension at the level of Islamic financial literacy has a significant effect on the use of Islamic financial services. This finding is consistent with Maski's (2010) research, which shows that belief has a significant influence on the preference for Islamic banks, in this case, Islamic financial services.

\section{Conclusion}

Based on the objectives and results of this study, it can be concluded that attitudes have a positive relationship but have no significant effect on the intention to use Islamic financial services. The subjective norms and perceived behavioral control positively influence Islamic financial services. As for moderating knowledge of the intention to use Islamic financial services on the subjective norm variable, it has a negative direction but significant effect. Perceived behavioral control variable has a positive relationship and significantly affects the intention to use Islamic financial services with the moderation of knowledge. Meanwhile, attitudes moderating knowledge do not significantly affect the intention to use Islamic financial services but positively.

Based on the above conclusions, it can be suggested in the following research to use knowledge as a mediating variable and add factors used as variables that have been proven to influence behavior intention, especially in Islamic financial services. 


\section{References}

Ajzen I (1985) From intentions to actions: a theory of planned behavior. Springer Berlin Heidelberg 11-39

Ajzen I (1991) The theory of planned behavior. Org Beh Plan Decis Process 50:179-211

Ajzen I (2002) Constructing a TPB questionnaire: conceptual and methodological considerations

Anon B (2009) Consumers doubt green efforts. Mark Manag 18:5-20

Rafia Afrozl \& Muhammad Mehedi Masud2 \& Rulia Akhtarl \& Md. Ashraful Islam3 \& Jarita Bt Duasal - Consumer purchase intention towards environmentally-friendly vehicles: an empirical investigation in Kuala Lumpur, Malaysia- Environ Sci Pollut Res - Springer-

Basu A, Hicks R (2008) Label performance and the willingness to pay for fair trade coffee: across-national perspective. Int J Consum Stud 32: 470-478

Bhattacharya CB, Sen S (2004) Doing better at doing good: when, why and how consumers respond to corporate social initiatives. Calif Manag Rev 47(1):9-24. doi:10.2307/3850493

Bockman S, Razzouk Y, Sirotnik B (2009) Going green - from left to center stage: an empirical perspective. J Am Acad Bus 14(2):8-17

Darnall N, Pointing C, and Vazquez-Brust DA (2012) Why consumers buy green. Green Growth Manag Transit Sustain Econ 287-308

Eck S (2009) Teures Gewissen. Werben \& Verkaufen 822

Ferguson K (2011) Consumer perceptions of green: are we expecting too much? Available at SSRN 1909604

Finisterra P, Arminda M, Raposo B, Lino M, Leal W (2009) Identifying the green consumer: a segmentation study. J TargetMeas AnalMark 17:17-25

Kanarattanavong A, Ruenrom G (2009) The model of corporate environmentalism: the effects of perceived market uncertainty upon marketing, environmental, and social performance. Bus Rev Camb 12(2): 140-147

Oskamp S (1977) Attitudes and opinions. Prentice-Hall, New Jersey

Otoritas Jasa Keuangan (2019), Survei Literasi Keuangan dan Keuangan Inklusif.

Sen S, Bhattacharya CB (2001) Does doing well always lead to better? Consumer reactions to corporate social responsibility. JMark Res 38(2):225-243, http://www.jstor.org/pss/1558626

Staats H (2003) Understanding pro-environmental attitudes and behavior: an analysis and review of research based on the theory of planned behavior. In: Bonnes M, Lee T, Bonaiuto M (eds) Psychological theories for environmental issues. Ashgate,

Aldershot Tikir A, Lehmann B (2011) Climate change, theory of planned behavior and values: a structural equation model with mediation analysis. Clim Chang 104(2):389-402

Vermeir I, Verbeke W (2006) Sustainable food consumption: exploring the consumer Battitude-behavioural intention^ gap. J Agric Environ Ethics 19(2):169-194

Young A (2004) The octagon model of volunteer motivations: results of a phen Abd Rahman, A., Asrarhaghighi, E., \& Ab Rahman, S. (2015). Consumers and Halal cosmetic products: knowledge, religiosity, attitude, and intention. Journal of Islamic Marketing, 6(1), 148163.

Anggelina, J., \& Japarianto, E. (2014). Analisis Pengaruh Sikap, Subjective Norm dan Perceived Behavioural Control terhadapa Purchase Intention Pelanggan Sogo Department Store di Tunjungan Plaza Surabaya.Jurnal StrategiPemasaran, 2(1), 1-7.

Anoraga, Pandji.(2010). Manajemen Bisnis.Jakarta: PT. Rineka

Kusuma, I. D., \& Untarini, N. (2014). Pengaruh Pengetahuan Produk Terhadap Niat Beli Dengan Sikap Sebagai Variabel Intervening. Jurnalllmu Manajemen, 2.

Ma, Y. (2005). The Role of Consumer Pengetahuan in Consumer Evaluations of Brand Extension Yun Ma A thesis submitted to Auckland University of Technology in partial fulfillment of the degree of Master of Business. Brand.The University of Technology in partial fulfillment of the degree of Master of Business. 
Karina Indah Rohmatunl, Citra Kusuma Dewi, 2017, Pengaruh Pengetahuan Dan Religiusitas Terhadap Niat Beli Pada Kosmetik Halal Melalui Sikap. Jurnal Ecodemica, Vol. 1 No. 1 April 2017omenological analysis. Int J Volunt Nonprofit Org 15(1):21-46

Rozandy, Rizki Aditya, (2016), Analisis Variabel-Variabel yang Mempengaruhi Tingkat Adopsi Teknologi dengan Metpde Partial Least Square (Studi Kasus Pada Sentra Industri Tahu DesaSendang, Kec.Banyakan, Kediri)", Jurnal Industria Vol 1 No 3, 151.

Juliandi, A. (2018). Structural equation model based partial least square (SEM-PLS): Menggunakan SmartPLS. Pelatihan SEM-PLS Program Pascasarjana Universitas Batam on December,16-17 2018. Batam: Universitas Batam. DOI: 10.5281/zenodo. 253800

Bellman, Lawrence M. 2009. Fashion Accessory Buying Intentions Among Female Millennials. Review of Business; 30 (1) pg: 46-57

Burhanudin, Erwin dan Siti Nurul Ngaini. 2005. Analisis Minat Konsumen untuk Bertransaksi pada Perbankan Syariah di Kota Yogyakarta. Sinergi, Kajian Bisnis dan Manajemen, h: 3140

Dominanto, Nedi Nugrah. 2008. Perbedaan Sikap terhadap Iklan, Merek dan Niat Beli Konsumen pada Iklan dengan Fear Appeal Tinggi dan Rendah pada Partisipan Wanita. Jurnal Ekonomi dan Bisnis 2 (2), h: 67-75

Downs, Danielle Symons et al. 2006. Youth Exercise Intention and Past Exercise Behaviour: Examining the Moderating Influences of Sex and Meeting Exercise Recommendations. American Alliance for Health, Physical Education, Recreation and Dance, 77 (1), pp: 9199

Dunn, Michael S et al. 2001. The Influence of Significant Others on Attitudes, Subjective Norms and Intentions Regarding Dietary Supplement Use Among Adolescent Athletes. ProQuest, 36 (143); pg 583-591

Ferdinand, Augusty. 2002. Structural Equation Modeling dalam Penelitian Manajemen Aplikasi Model-model Rumit dalam Penelitian untuk Tesis Magister \& Disertasi Doktor. Edisi Kedua. Semarang : BP UNDIP

Gan, Christopher et al. 2008. Consumers' Purchasing Behaviour towards Green Products in New Zealand. Innovative Marketing, 4 (1), pp: 93-102

Istiana, dkk. 2010. Pengaruh Sikap, Norma Subyektif dan Kontrol Keperilakuan Terhadap Niat dan Perilaku Beli Produk Susu Ultra High Temperature. Semiloka Nasional.

Mada, Yudhi Prasetya. 2005. Analisis Pengaruh Sikap terhadap Perilaku, Norma Subyektif dan Kontrol Kepemilikan yang Dirasakan terhadap Niat dan Perilaku Konsumen. Infestasi, 1 (1), h: 79-88

Marhaini. 2008. Analisis Perilaku Konsumen dalam Pembelian Komputer Merek Acer (Studi Kasus: Mahasiswa Fakultas Ekonomi Universitas Sumatera Utara). Jurnal Manajemen Bisnis, 1 (3), h: 89-96

Mukodim, Didin dan Erliansyah. 2007. Variabel yang Mempengaruhi Keputusan Konsumen dalam Membeli Produk Telepon Seluler. Jurnal Ekonomi Bisnis 12 (3), h: 220-229

Sigit, Murwanto. 2006. Pengaruh Sikap dan Norma Subyektif terhadap Niat Beli Mahasiswa sebagai Konsumen Potensial Produk Pasta Gigi Close Up. Jurnal Siasat Bisnis, ll (l), h: 81-91

Simamora, Bilson. 2002. Panduan Riset Perilaku Konsumen. Gramedia: Jakarta

Suprapti, Sri. 2010. Perilaku Konsumen Pemahaman Dasar dan Aplikasinya dalam Strategi

Pemasaran. Udayana University Press : Denpasar

Sugiyono. 2009. Metode Penelitian Bisnis. Alfabeta: Bandung

Sumarwan, Ujang. 2004. Perilaku Konsumen. Ghalia Indonesia: Bogor

Tang, Zhongjun et al. 201l. Antecedents of Intention to Purchase Mass Customized Products. Journal of Product \& Brand Management. 20 (4), pp: 316-326

Winarto. 2008. Pengaruh Sikap dan Norma Subyektif terhadap Minat dan Keputusan Memilih Kuliah di Universitas Hang Tuah Surabaya. Aplikasi Administrasi, 10 (1), h: 5164

Ilham Maulana Saud, 2016, Pengaruh Sikap dan Persepsi Kontrol Perilaku Terhadap Niat 
Whistleblowing Internal-Eksternal dengan Persepsi Dukungan Organisasi Sebagai Variabel Pemoderasi, Jurnal Akuntansi dan Investasi, Vol. 17 No. 2, Hlm: 209-219

Mia Muktiana Banowati \& Maimun Sholeh, 2018), FAKTOR-FAKTOR YANG MEMPENGARUHI NIAT MENABUNG DI BANK SYARIAH, Jurnal Ekonomi \& Pendidikan, 15(1)

Siaran Pers Survei OJK 2019 Indeks Literasi Dan Inklusi Keuangan Meningkat, 7 November 2019, SP 58/DHMS/OJK/XI/2019

Kunti Saptasari, (2016), Pengaruh Religiusitas, Pengetahuan,dan Persepsi Nilai Kualitas terhadap Sikap dan Niat Menggunakan Bank Syariah di Indonesia, Tesis, UII Yogyakarta

Ida Royani Pasi (2017), Pengaruh Pengetahuan Dan Sikap Terhadap Perilaku Masyarakat Pada Bank Syariah, Jurnal Al-Qasd: Islamic Economic Alternative, Vol 1, No 2., DOI: http://dx.doi.org/10.22303/al-qasd.1.2.2017.189-201

Muhammad Muflih, Diharpi Herli Setyowati, Hasbi Assidiki, Radia Purbayati, Destian Arshad, Ruhadi Ruhadi (2020), Niat Perilaku Pengguna Tabungan Koperasi Syariah: Peran Pengetahuan Produk, Kepercayaan, Persepsi Keuntungan, dan Persepsi Kualitas, Vol 11 No 1 (2020): Prosiding llth Industrial Research Workshop and National Seminar (IRWNS), DOI: https://doi.org/10.35313/irwns.vllil.2178

Abdul Haris Romdhoni, Dita Ratna sari (2018), Pengaruh Pengetahuan, Kualitas Pelayanan, Produk, dan Religiusitas terhadap Minat Nasabah untuk Menggunakan Produk Simpanan pada Lembaga Keuangan Mikro Syariah, Jurnal ilmiah Ekonomi Islam, Vol 4, No 02 (2018)

Siti Nur Annisa Amalia (2018), Faktor-Faktor Yang Mempengaruhi Minat Individu Terhadap Financial Technology (Fintech) Syariah (Paytren) Sebagai Salah Satu Alat Transaksi Pembayaran (PendekatanTechnology Acceptance Model (TAM) dan Theory Of Planned Behaviour (TPB), Jurnal Iqtishoduna, Vol 9 No 1 (2018): Juni 2018 , https://doi.org/10.20414/iqtishaduna.v9il.687

Muhammad Akib, Bedjo Santoso (2019), Pengaruh Subjective Norm Dan Perceived Behavioural Control Terhadap Intention To Use Product Bank Syariah Melalui Islamic Spiritual Value, presiding 2019: The 6th NCAB

Dhian Wahyuni, Hasan Basri, M. Shabri, (2019), Pengaruh Sikap, Norma Subjektif, Perceived Behavioural Control Dan Religiusitas Terhadap Niat Memiliki Rumah Berbasis Pembiayaan Syariah Di Kota Banda Aceh, Jurnal Administrasi Akuntansi Vol 6, No 2

Mudrikah, Siti (2018) Analisis pengaruh persepsi return pada keputusan berinvestasi di saham syariah dengan pengetahuan sebagai variabel moderasi : studi kasus galeri investasi BEI FEBI UIN Walisongo Semarang. Undergraduate (SI) thesis, UIN Walisongo Semarang.

Arifianto, Mochammad Yoga. (2020), Pengaruh Promosi dan Persepsi Nilai terhadap Minat Menabung di Bank Syariah dengan Religiusitas Sebagai Variabel Moderasi (Studi Pada Bank BRI Syariah KCP Magelang). Skripsi. Fakultas Ekonomi dan Bisnis Islam Program Studi Sl Perbankan Syariah IAIN Salatiga. Pembimbing: Dr. Abdul Aziz N.P., S.Ag., MM

Wijayantie, Meitry Nurachma and Sunarsih, Uun (2020) Pengaruh Disposable Income dan Sharia Compliance terhadap Keputusan Menabung di Perbankan Syariah dengan Literasi Keuangan Syariah sebagai Variabel Moderasi (Studi Kasus Pada Mahasiswa di Provinsi DKI Jakarta). Skripsi thesis, Sekolah Tinggi Ilmu Ekonomi Indonesia Jakarta.

Hamim, Muhammad (2018) Pengaruh Religiusitas dan Kepercayaan terhadap Preferensi Masyarakat Menabung di Bank Syariah Kabupaten Boyolali dengan Pelayanan sebagai variabel moderasi Skripsi. Other thesis, IAIN Salatiga.

Hayati, Roh (2020) Pengaruh Word Of Mouth, Bauran Pemasaran, Kualitas Pelayanan Dan Kepatuhan Syariah Terhadap Minat Menabung Masyarakat Pada Bank Syariah Dengan Religiusitas Sebagai Variabel Moderasi (Studi Kasus pada Masyarakat Kecamatan Gubug Grobogan).

Riza, NovianaDiah. (2018). Analisis Pengaruh E-Banking dan Kualitas Pelayanan Terhadap Loyalitas Nasabah Di Perbankan Syariah Dengan Komitmen Keagamaan Sebagai Variabel Moderasi (Studi Kasus pada Nasabah BRI Syariah di IAIN Salatiga). Skripsi, 
Ana Sardiana./Li Falah-Jurnal Studi Ekonomi dan Bisnis Islam, Volume 6 (No.1 2021)2507

FakultasEkonomidanBisnis Islam Program Studi Sl-Perbankan Syariah IAIN Salatiga. 